Жемела Г. П., доктор сільськогосподарських наук, професор, Шевніков Д. М., аспірант *

Полтавська державна аграрна академія

\title{
ФОТОСИНТЕТИЧНА ПРОДУКТИВНІСТЬ ПОСІВІВ ПШЕНИЦІ ТВЕРДОӤ ЯРОЇ ЗАЛЕЖНО ВІД МІНЕРАЛЬНИХ ДОБРИВ ТА БІОПРЕПАРАТІВ
}

\author{
Рецензент - доктор сільськогосподарських наук, професор С. М. Каленська
}

Застосування мінеральних добрив та інокулячії насіння пшениці ярої біопрепаратами позитивно вплинуло на фотосинтетичну продуктивність рослин. Формування листкової поверхні пшениці залежало як від фону мінерального живлення, так і від застосування мікробіологічних препаратів. На ділянках без удобрення обробка насіння біопрепаратами сприяла збільщенню площі листків на 20,3\% за використання «Поліміксобактерину», 20,5\% - «Діазофіту» та 23,9\% - суміші изих двох препаратів. Дані заходи створюють сприятливі умови живлення для формування оптимальної площі листкового апарату та ефективної фотосинтетичної продуктивності.

Ключові слова: пшениця тверда яра, мінеральні добрива, «Поліміксобактерин», «Діазофіт», площиа листків, фотосинтез.

Постановка проблеми. 3 появою нових сортів пшениці ярої виникла потреба встановити як змінюються показники фотосинтетичної діяльності у посівах залежно від умов мінерального живлення, адже між цими величинами та врожайністю рослин існує тісна пряма й зворотна кореляційна залежність. В умовах Лівобережної частини Лісостепу це питання вивчено недостатньо. Для оптимального проходження фотосинтезу посів повинен мати певну площу листкової поверхні. Проте потрібно розрізняти листкову поверхню як засіб нагромадження пластичних речовин для формування врожайності зерна, коренів, бульб, різних плодів i листкову масу культур, які вирощують для одержання кормів (зелених, сіна, сінажу та ін.). У першому випадку (формування врожайності зерна) надлишкова листкова поверхня не сприятиме високій врожайності культури, постільки частина листків буде затінена ії верхніми ярусами.

Крім того, ця затінена частина листків не лише не дає продуктивної віддачі, а $є$ по суті зайвою, оскільки для іï формування використовується чимало поживних речовин.
Аналіз основних досліджень і публікацій, у яких започатковано розв'язання проблеми. Врожайність рослин визначається, передусім, розмірами та продуктивністю роботи фотосинтетичного апарату, який у процесі росту і розвитку рослин повинен якомога скоріше досягти оптимального розміру. Одним із факторів, що регулює площу асиміляційної поверхні, $є$ поживний режим рослин. Тому в період вегетації необхідно створювати найсприятливіші умови живлення, аби рослини сформували оптимальну площу листкового апарату для ефективної фотосинтетичної діяльності. Вивченню цього питання на посівах пшениці ярої присвячено низку робіт [2-3]. Біологічне значення розмірів листкової поверхні полягає в тому, що від них залежить ступінь поглинання посівами фотосинтетичної активної радіації (ФАР). Саме для характеристики потужності асиміляційного апарату прийнято визначати фотосинтетичний потенціал (ФП) - показник, що характеризує можливість посівів використовувати для фотосинтезу ФАР. Вважають, що високопродуктивні посіви мають ФП не менше 2,2-3,0 млн м² за добу в розрахунку на 100 днів фактичної вегетації [1].

Мета і завдання дослідження. Метою наших досліджень було вивчити особливості формування фотосинтетичної поверхні рослин пшениці твердої ярої залежно від умов вирощування; встановити норми внесення мінеральних добрив за умови застосування біопрепаратів, що сприяють оптимальному розвитку надземної й підземної частин рослин i забезпечують формування стабільно великих врожаїв зерна незалежно від умов погоди.

Завдання досліджень - вивчити особливості фотосинтетичної продуктивності рослин за використання передпосівної обробки насіння різними біологічними препаратами залежно від рівня мінерального живлення та встановити їхнє оптимальне співвідношення для забезпечення формування стабільної врожайності зерна пшениці твердої ярої з високими якісними характеристиками.

* Науковий керівник - доктор сільськогосподарських наук, професор Г. П. Жемела 
Матеріали і методи досліджень. Основні експерименти проводили на дослідному полі Полтавського інституту АПВ ім. М. І. Вавилова в 2010-2012 роках. Вивчали вплив передпосівної обробки насіння мікробіологічними препаратами залежно від розрахованого балансовим методом фону мінерального живлення рослин на урожайність 3 т/га зерна. Дослідження проводили на шести фонах мінерального живлення: без добрив - контроль; $\mathrm{N}_{45} ; \mathrm{P}_{45} \mathrm{~K}_{30} ; \quad \mathrm{N}_{45} \mathrm{P}_{45} \mathrm{~K}_{30}$; $\mathrm{N}_{23} \mathrm{P}_{23} \mathrm{~K}_{15}$; солома попередника $+\mathrm{N}_{10}$ на кожну тону побічної продукції. Досліди закладали в триразовому повторенні, облік врожайності провели 3 ділянки площею $25 \mathrm{~m}^{2}$.

Результати досліджень. Наші дослідження показали, що посушливі погодні умови 2010 року, передусім другої половини вегетації, сприяли значному зменшенню кущення рослин. Густота рослин не залежала від дії мінеральних добрив $\mathrm{i}$ біопрепаратів. Більш суттєвий вплив здійснювали ці засоби на величину листкової поверхні (див. табл.).

У фазу колосіння площа листкової поверхні за використання біопрепаратів становила 30,531,7 , без інокуляції - 25,9 тис. м²/га. За використання біопрепаратів на фоні мінеральних добрив $\mathrm{N}_{45} \mathrm{P}_{45} \mathrm{~K}_{30}$ цей показник збільшився до $34,3-$ 38,0 , без інокуляції - до 29,4 тис. м²/га. Інші варіанти удобрення також були достатньо ефективними: на фоні азотних добрив кращу дію для наростання листкової поверхні здійснював «Діазофіт», на фоні фосфорно-калійних добрив «Поліміксобактерин».

Дослідження, проведені в 2011 році, показали, що внесення мінеральних добрив сприяло збільшенню площі листків у пшениці твердої на 13,7-57,4 \% порівняно 3 ділянками без їхнього застосування. В середньому за вегетацію найбільш потужний листковий апарат формували рослини на ділянках із внесенням максимальної кількості добрив $\left(\mathrm{N}_{45} \mathrm{P}_{45} \mathrm{~K}_{30}\right)$ - від 36,1 до 42,8 тис. $\mathrm{M}^{2} /$ га залежно від застосування біопрепаратів. Найменшою площею листків характеризувалися рослини на ділянках без внесення добрив та без інокуляції $\left(25,5-25,9\right.$ тис. $\mathrm{M}^{2} /$ га). За внесення половинної дози добрив $\left(\mathrm{N}_{23} \mathrm{P}_{23} \mathrm{~K}_{15}\right)$

Площа листкової поверхні пшениці твердої ярої

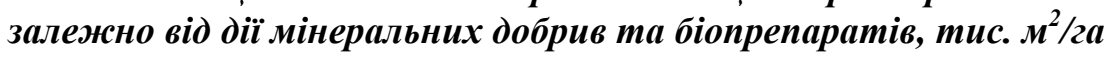

\begin{tabular}{|c|c|c|c|c|c|}
\hline \multirow[b]{2}{*}{$\begin{array}{c}\text { Варіанти } \\
\text { удобрення }\end{array}$} & \multirow[b]{2}{*}{ Рік } & \multicolumn{4}{|c|}{ Інокуляція зерна мікробіопрепаратами } \\
\hline & & без інокуляції & $\begin{array}{c}\text { «Полі- } \\
\text { міксобактерин» }\end{array}$ & «Діазофіт» & $\begin{array}{c}\text { суміш «Полі- } \\
\text { міксобактерину» } \\
\text { та «Діазофіту» }\end{array}$ \\
\hline \multirow{4}{*}{ Без добрив } & 2010 & 25,9 & 31,7 & 30,5 & 31,6 \\
\hline & 2011 & 25,5 & 30,7 & 31,4 & 32,9 \\
\hline & 2012 & 24,0 & 28,3 & 29,1 & 28,9 \\
\hline & Середнє & 25,1 & 30,2 & 30,3 & 31,1 \\
\hline \multirow{4}{*}{$\mathrm{N}_{45} \mathrm{P}_{45} \mathrm{~K}_{30}$} & 2010 & 29,4 & 38,0 & 34,3 & 37,7 \\
\hline & 2011 & 36,1 & 38,9 & 38,3 & 42,8 \\
\hline & 2012 & 30.2 & 37,1 & 36,4 & 38,4 \\
\hline & Середнє & 31,9 & 38,0 & 36,3 & 39,6 \\
\hline \multirow{4}{*}{$\begin{array}{c}\text { Солома }+\mathrm{N}_{10} \\
\text { на тонну побічної } \\
\text { продукції }\end{array}$} & 2010 & 23,6 & 32,3 & 30,7 & 35,4 \\
\hline & 2011 & 33,7 & 37,4 & 37,7 & 43,8 \\
\hline & 2012 & 30,4 & 31,9 & 30,4 & 30,2 \\
\hline & Середнє & 29,2 & 33,9 & 32,9 & 36,4 \\
\hline \multirow{4}{*}{$\mathrm{N}_{23} \mathrm{P}_{23} \mathrm{~K}_{15}$} & 2010 & 25,9 & 28,2 & 31,9 & 33,3 \\
\hline & 2011 & 33,2 & 37,8 & 35,8 & 38,5 \\
\hline & 2012 & 26,3 & 29,4 & 30,6 & 30,9 \\
\hline & Середнє & 28,4 & 31,8 & 32,8 & 34,2 \\
\hline \multirow{4}{*}{$\mathrm{N}_{45}$} & 2010 & 25,4 & 27,3 & 34,6 & 34,1 \\
\hline & 2011 & 32,7 & 34,2 & 34,0 & 35,0 \\
\hline & 2012 & 26,0 & 27,5 & 28,8 & 33,5 \\
\hline & Середнє & 28,4 & 31,8 & 32,8 & 34,2 \\
\hline \multirow{4}{*}{$\mathrm{P}_{45} \mathrm{~K}_{30}$} & 2010 & 25,7 & 30,1 & 33,7 & 32,5 \\
\hline & 2011 & 31,0 & 32,9 & 34,1 & 33,8 \\
\hline & 2012 & 26,0 & 29.8 & 32.7 & 32,0 \\
\hline & Середнє & 27,6 & 30,9 & 33,5 & 32,8 \\
\hline
\end{tabular}


площа листкової поверхні мала середні показники (33,2-38,5 тис. м²/га). Досить велика площа листкової поверхні була на варіанті солома попередника $+\mathrm{N}_{10}$ на тонну побічної продукції 33,7-43,8 тис. м²/га. За внесення азотних добрив $\mathrm{N}_{45}$ або фосфорно-калійних $\mathrm{P}_{45} \mathrm{~K}_{30}$ не відбулося збільшення даного показника, відповідно, 32,735,0 i 31,0-33,8 тис. $^{2} /$ га. Інокуляція насіння «Поліміксобактерином» і «Діазофітом» сприяла збільшенню площі листкової поверхні рослин, особливо в умовах застосування мінеральних добрив.

У 2012 році погодні умови були досить посушливими, 3 незначною кількістю опадів, що негативно вплинуло на формування листкової поверхні рослин. На варіантах без застосування добрив дія біопрепаратів позитивною виявилася під впливом «Діазофіту» - площа листкової поверхні становила 29,1, без інокуляції 24,0 тис. м $^{2}$ га. За внесення $\mathrm{N}_{45} \mathrm{P}_{45} \mathrm{~K}_{30}$ найбільшою листкова поверхня спостерігалася за сумісного застосування «Діазотофіту» та «Поліміксобактерину» - 38,4, дещо меншою - за обробки насіння препаратами окремо, відповідно, 36,4 i 37,1 , без інокуляції - 30,2 тис. $\mathrm{м}^{2} /$ га. На інших варіантах удобрення площа листкової поверхні під впливом біопрепаратів збільшувалася на 0-4,9 \% (солома $+\mathrm{N}_{10}$ на тонну побічної продукціï), на 11,7-17,2\% $\left(\mathrm{N}_{23} \mathrm{P}_{23} \mathrm{~K}_{15}\right)$, на 5,8-32,0 $\left(\mathrm{N}_{45}\right)$, на $14,6-23 \%\left(\mathrm{P}_{45} \mathrm{~K}_{30}\right)$.

Площа листкової поверхні пшениці твердої ярої залежно від дії мінеральних добрив та біопрепаратів у середньому за три роки досліджень відображена на рисунку 1. Формування листкової поверхні залежало як від фону мінерального живлення, так i від застосування мікробіологічних препаратів. На ділянках без удобрення обробка насіння біопрепаратами сприяла збільшенню площі листків до 30,2 тис. $\mathrm{M}^{2} /$ га $(20,3 \%)$ за використання «Поліміксобактерну», 30,3 тис. $\mathrm{m}^{2} /$ га (20,5\%) - «Діазофіту» та 31,1 тис. $\mathrm{m}^{2} /$ га $(23,9 \%)$ - суміші цих двох препаратів. За внесення дози добрив $\mathrm{N}_{45} \mathrm{P}_{45} \mathrm{~K}_{30}$ листкова поверхня становила 31,9 тис. $\mathrm{m}^{2} /$ га, застосування «Поліміксобактерину» забезпечило збільшення на 19,1 \%, «Діазофіту»- на 13,8, суміші препаратів - на 24,1\%. За внесення половинної дози добрив $\mathrm{N}_{23} \mathrm{P}_{23} \mathrm{~K}_{15}$ площа листкової поверхні зменшилася до 29,2 тис. м²/га, а за використання біопрепаратів до попередньої дози добрив зменшило цей показник на 12,0; 10,3; 8,8 \% відповідно.

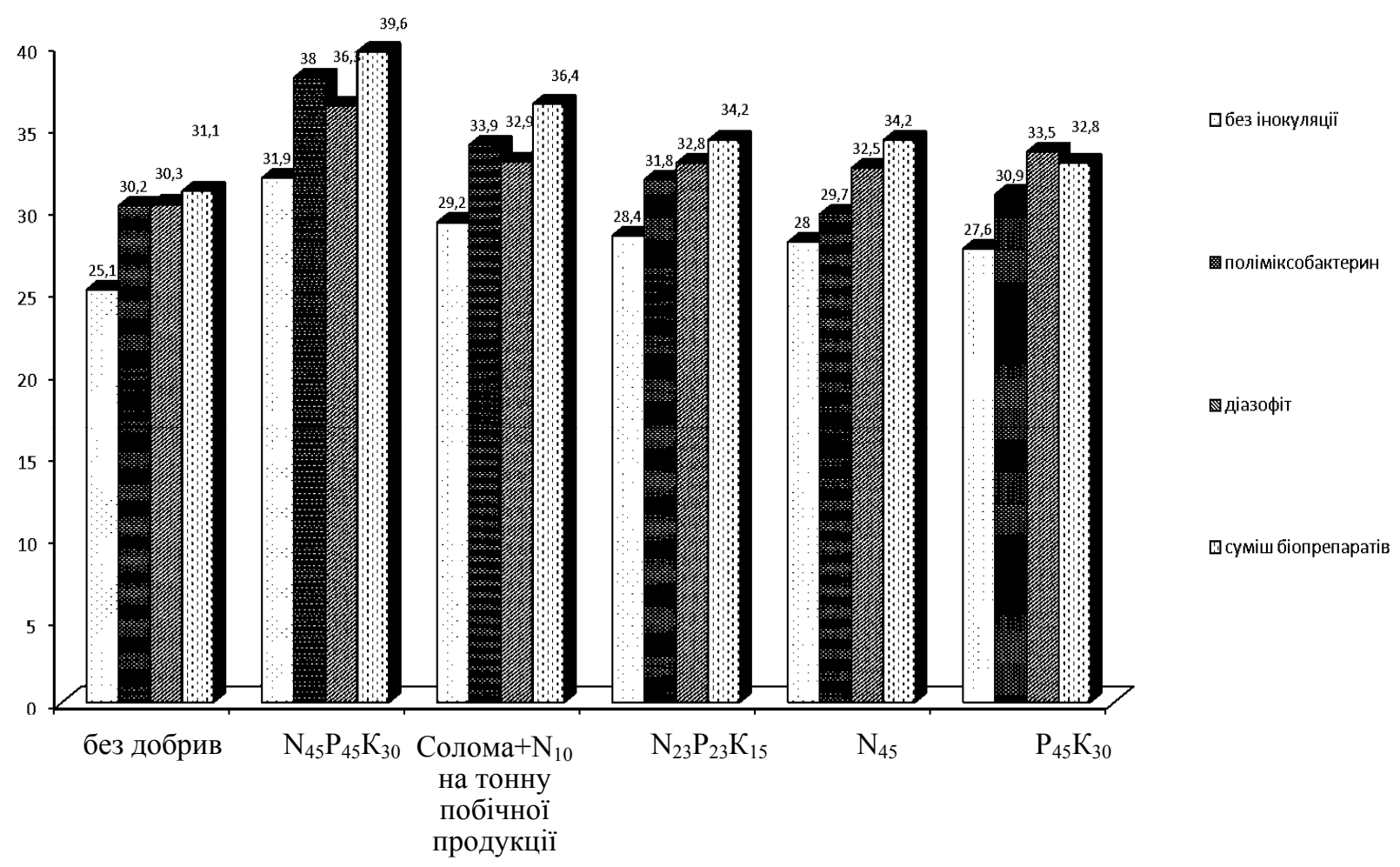

Рис. 1. Площа листкової поверхні пщениці твердої ярої залежно від дії мінеральних добрив та біопрепаратів, тис. $\boldsymbol{M}^{2} / 2 a$ (середнє за 2010-2012 рр.) 


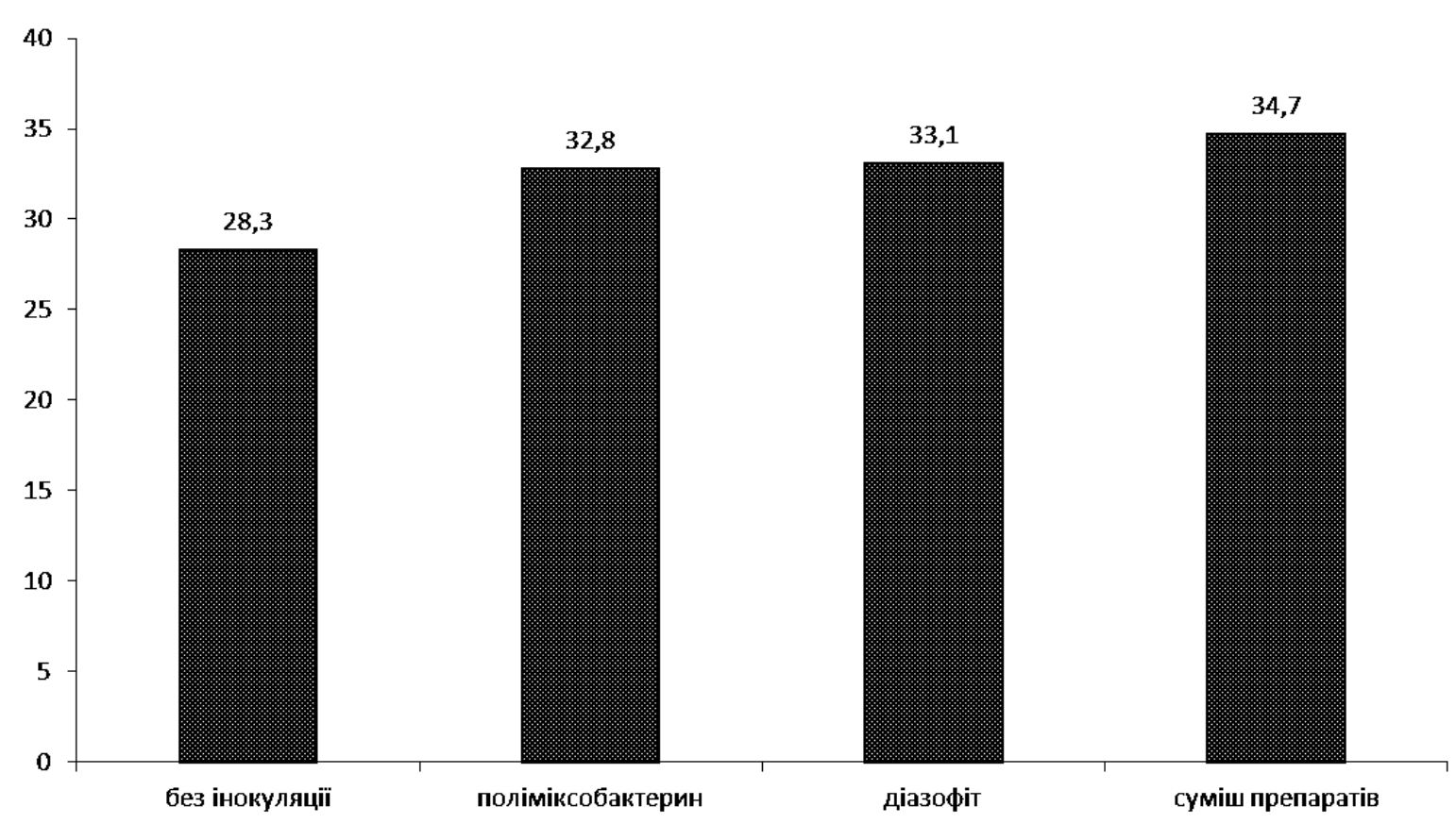

Рис. 2. Площа листкової поверхні пшениці твердої ярої залежсно від впливу інокуляції зерна біопрепаратами, тис. м $^{2} 2$ a (2010-2012 рр.)

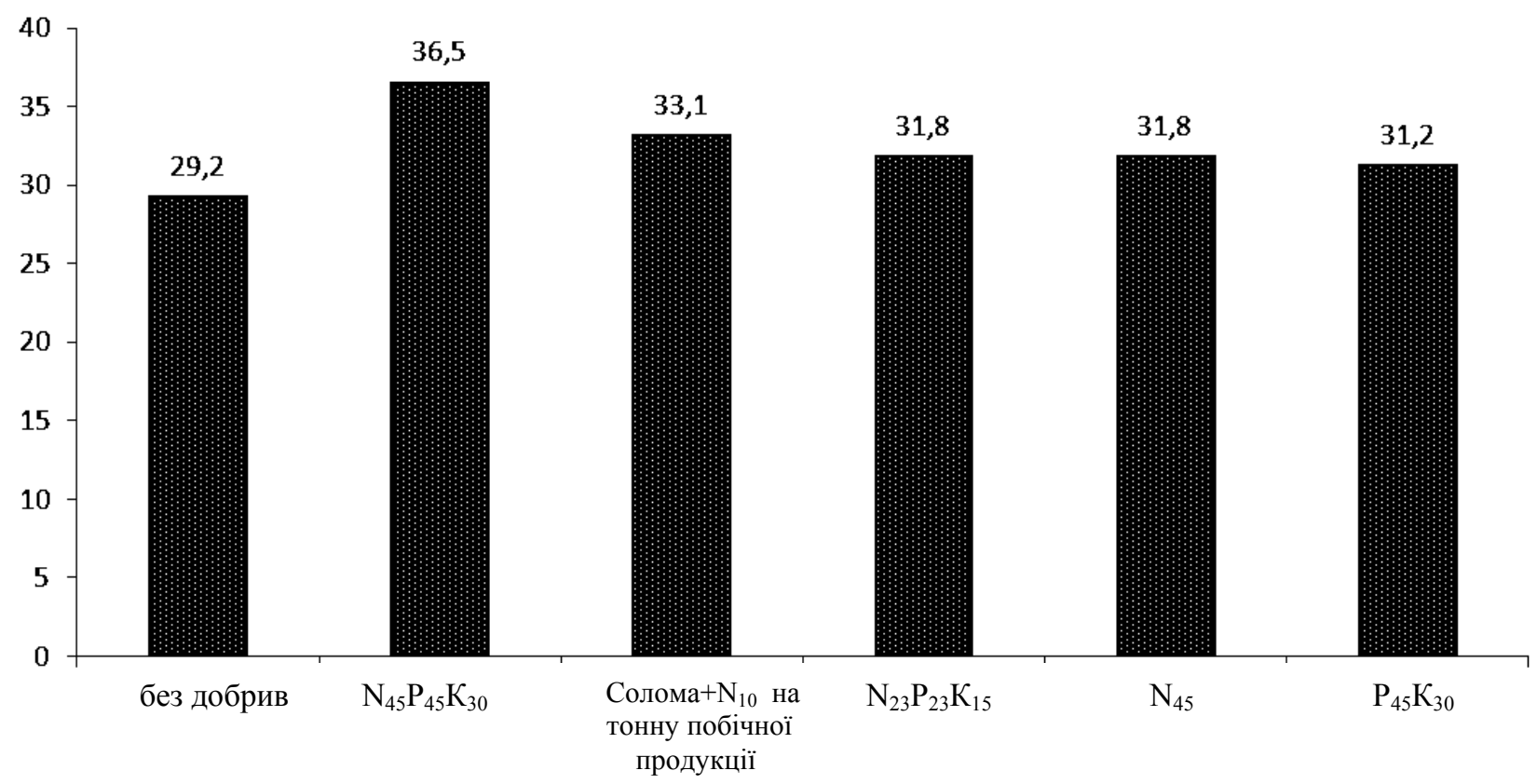

Рис. 3. Площа листкової поверхні пшениці твердої ярої залежно від впливу різних фонів

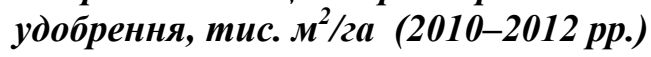

За внесення лише азотних добрив $\mathrm{N}_{45}$ площа листкової поверхні становила 28,0 тис. $\mathrm{m}^{2} /$ га, за використання біопрепаратів: «Поліміксобактерину» 29,7 тис. $\mathrm{м}^{2} /$ га, «Діазофіту» - 32,5, суміші препаратів - 34,2 тис. $\mathrm{m}^{2} /$ га. Площа листкової поверхні при застосуванні удобрення фосфорно-калійними добривами $\mathrm{P}_{45} \mathrm{~K}_{30}$ становила, відповідно, 27,6; 30,9; 33,5;
32,8 тис. $\mathrm{m}^{2} /$ га. Досить ефективним був удобрений фон солома $+\mathrm{N}_{10}$ на тонну побічної продукції, поскільки величина листкової площі на ділянках досліду була досить значною $\left(29,2\right.$ тис. м $^{2} /$ га), а за використання біопрепаратів, відповідно, 33,9; 32,9; 36,4 тис. $\mathrm{m}^{2} /$ га. 
Для визначення впливу технологічних заходів визначали конкретну частку біопрепаратів та фону удобрення на площу листкової поверхні пшениці твердої ярої (рис. 2 і 3). Математичний аналіз, проведений за всіма варіантами досліду, дав змогу встановити, що площа листків без застосування інокуляції біопрепаратами становила 28,3 тис. ${ }^{2} /$ га. Інокуляція насіння «Поліміксобактерином» сприяла збільшенню цього показника до 32,8, «Діазофітом» - до 33,1, сумішшю препаратів - до 34,7 тис. $\mathrm{M}^{2} /$ га. Щодо фону мінерального живлення, то площа листкової поверхні мала такі значення: без добрив 29,2 тис. $\mathrm{m}^{2} /$ га; $\mathrm{N}_{45} \mathrm{P}_{45} \mathrm{~K}_{30}$ - 36,5 тис. $\mathrm{m}^{2} /$ га, або збільшилася на $25,0 \%$; солома $+\mathrm{N}_{10}$ на тонну побічної продукції - 33,1 тис. м²/га, або збільшилася на $13,4 \% ; \mathrm{N}_{23} \mathrm{P}_{23} \mathrm{~K}_{15}-31,8$ тис. $\mathrm{m}^{2} /$ га, або збільшилася на $8,9 \% ; \mathrm{N}_{45}-31,8$ тис. $\mathrm{m}^{2} /$ га, або збільшилася на $8,9 \% ; \mathrm{P}_{45} \mathrm{~K}_{30}-31,2$ тис. $\mathrm{m}^{2} /$ га, або збільшилася на $3,5 \%$.

\section{Висновки:}

1. Формування листкової поверхні пшениці твердої ярої залежало як від фону мінерального живлення, так і від застосування мікробіологічних препаратів. На ділянках без удобрення обробка насіння біопрепаратами сприяла підвищенню показника площі листкової поверхні на

\section{БІБЛІОГРАФІЯ}

1. Антал T. В. Вплив добрив на урожайність сортів пшениці ярої твердої в умовах північної частини Лісостепу / Т. В. Антал // Тези доповідей Міжнародної науково-практичної конференції м. Біла Церква, 26-28 лютого. - 2008. - С. 3.

2. Барановский П. М., Копьтциова В. С., Даниличев С. Н. Фотосинтез и урожай яровой пшеницы // Зерновое хозяйство. - 1980. - № 12. - С. 30.

3. Кумаков В. А. Биологические основы возделы-
20,3 \% за використання «Поліміксобактерину», на 20,5 \% - «Діазофіту» та 23,9 \% - суміші цих двох препаратів.

2. За внесення добрив $\mathrm{N}_{45} \mathrm{P}_{45} \mathrm{~K}_{30}$ листкова поверхня становила 31,9 тис. $\mathrm{m}^{2} /$ га, застосування «Поліміксобактерину» привело до їі збільшення на 19,1 \%, «Діазофіту» - на 13,8, суміші препаратів на $24,1 \%$. За внесення тільки азотних добрив $\mathrm{N}_{45}$ площа листкової поверхні становила 28,0 тис. м²/га, за використання біопрепаратів «Поліміксобактерину» - 29,7 тис. ${ }^{2} /$ га, «Діазофіту» - 32,5, суміші препаратів - 34,2 тис. м²/га.

3 . Ефективним був удобрений фон солома + $\mathrm{N}_{10}$ на тонну побічної продукції, оскільки величина листкової площі на ділянках досліду була досить значною $\left(29,2\right.$ тис. $\mathrm{m}^{2} /$ га), а за використання біопрепаратів, відповідно, 33,9; 32,9; 36,4 тис. $\mathrm{m}^{2} /$ га.

4. Найважливішими факторами, що регулюють величину асиміляційної поверхні, є поживний режим грунту, який значно поліпшує передпосівна інокуляція насіння пшениці твердої ярої біопрепаратами «Поліміксобактерином» та «Діазофітом». Ці заходи створюють сприятливі умови живлення для формування оптимальної площі листкового апарату та ефективної фотосинтетичної діяльності.

вания яровой пшеницы по интенсивной технологии. - М. : Росагропромиздат, 1988. - 104 с.

4. Ничипорович A. А. Фотосинтез и теория получения высоких урожаев. - М. : Изд-во АН СССР, 1956. $-330 \mathrm{c}$.

5. Шатилов И. С., Чаповская Г. В., Замараев А. Г. Фотосинтетический потенциал и урожай зерновых культур. - Изв. ТСХА, Вып. 3, 1979. C. 18-30. 